\title{
6,8-disübstitüe kinolin analoglarının anti kanser ajanlar olarak yapı aktivite (SAR) çalışması
}

\section{The structure activity relationship (SAR) study of 6,8-disubstituted quinoline derivatives as anti cancer agents}

\author{
Salih ÖKTEN ${ }^{1 *}$, Osman ÇAKMAK², Şaban TEKIN³
}

${ }^{1}$ Kırıkkale Üniversitesi, Eğitim Fakültesi, Matematik ve Fen Bilimleri Eğitimi Bölümü, Kırıkkale, Türkiye

2̇̇stanbul Gelişim Üniversitesi, Sağlık Bilimleri Yüksekokulu, 34315 Avcılar, İstanbul, Türkiye

${ }^{3}$ Gen Mühendisliği ve Biyoteknoloji Enstitüsü, Tübitak MAM, 41470, Gebze, Kocaeli, Türkiye

\section{öz}

Amaç: Bu çalışmada, 6,8-disübstitüe kinolin türevlerinin antikanser potansiyelleri, etki mekanizmaları ve farklı sübstituentlerin aktiviteye etkilerinin belirlemesi amaçlanmıştır.

Gereç ve Yöntem: Tetrahidrokinolin molekülü (1), moleküler brom $\left(\mathrm{Br}_{2}\right)$ ile reaksiyonu ve müteakiben aromatlaştırılması ile 6,8-dibromo-1,2,3,4-tetrahidrokinolin (6,8-dibromoTHQ, 2) ve 6,8-dibromokinolin (6,8-diBrQ, 3) elde edildi. Bu moleküller, yer değiştirme ve Suzuki Kenetleme reaksiyonları sonucu ile 6,8-dimetoksikinolin (6,8-diMeOQ, 4), 6,8-disiyanokinolin (6,8-diCNQ, 6) ve 6,8-difenilkinolin'e (6,8-diPhQ, 5) dönüştürüldü. Sentezlenen bileşiklerin (2-6) antikanser potansiyellerinin ortaya çıkartmak için HeLa (İnsan rahim kanser hücresi), HT29 (Kolon kanseri) ve C6 (Sıçan beyin kanser hücresi) hücre hatlarına karşı BrDU hücre proliferasyonu, LDH sitotoksisite, DNA bantlaşma ve DNA Topoizomeraz I inhibisyon testleri uygulandı.

Bulgular: HT29 hücre hatlarında ise, bileşikler 2, 3, 4 ve 5 numaralı bileşikler hücre proliferasyonunu inhibe etmiştir fakat HeLa ve C6 hücre hatlarında sadece 6,8-dibromoTHQ 2 ve 6,8-diPhQ 5 bileşikleri önemli derecede antiproliferatif etki göstermiştir. 6,8-dibromoTHQ 2, tüm hücre hatlarında yüksek inhibisyon gösterirken, sitotoksik etki göstermemiştir. 6,8-dibromoTHQ 2 DNA bantlaştırma ve Topoizomeraz I enziminin inhibe edebilme özelliği ortaya çıkarılmıştır.

Sonuçlar: Kinolin halkasının C-6 ve C-8 konumlarında fonksiyonel grupların değiştikçe farklı aktiviteleri gözlenmiştir. 6,8-DiBrTHQ 2 ve 6,8-diPhQ 5 moleküllerinin antiproliferatif ve apoptotik aktivite göstermeleri sebebiyle antikanser ajan olma potansiyelleri belirlenmiştir.

Anahtar Kelimeler: Kinolin, tetrahidrokinolin, bromokinolin, fenilkinolin, antikanser, sitotoksisite, apoptoz, Topoizomeraz I inhibitörü 


\section{ABSTRACT}

Aim: In this study, determination of the anticancer potentials of 6,8-disubstituted quinolines, mechanisms of their action and effects of different substituents to anticancer activity were aimed.

Material and Method: Reaction of tetrahydroquinoline (1) with molecular bromine $\left(\mathrm{Br}_{2}\right)$ and then aromatization of product afforded 6,8-dibromo-1,2,3,4-tetrahydroquinoline (6,8-dibromoTHQ, 2) and 6,8-dibromoquinoline (6,8-diBrQ, 3). These compounds were converted to corresponding derivatives 6,8-dimethoxyquinoline (6,8-diMeOQ, 4), 6,8-dicyanoquinoline (6,8-diCNQ, 6) and 6,8-diphenylquinoline (6,8-diPhQ, 5) via nucleophilic substitution and Suzuki cross coupling reactions. BrDU cell proliferation, LDH cytotoxcity, DNA laddering and DNA Topoisomerase I inhibition assays were applied to synthesized compounds (2-6) against HeLa, HT29 and C6 cell lines to determine their anti cancer potentials.

Results: Although only $\mathbf{2}$ and $\mathbf{5}$ have antiproliferative effect against against HeLa (Human Cervix Carcinoma) and C6 (Rat Brain Tumor Cells) cell lines, compounds $\mathbf{2 , 3 , 4}$ and $\mathbf{5}$ inhibited the proliferation of HT29 (Human Colorectal Adenocarcinoma) cell line. Moreover, 6,8-dibromoTHQ 2 showing significant inhibition against all cell lines did not showed cytotoxic effect. However, compound $\mathbf{2}$ have caused DNA fragmantation and inhibited Topoisomerase I enzyme.

Conclusion: The exchange of functional groups of quinoline skeleton at C- 6 and C-8 positions have caused different anticancer activities. The potential of being anticancer agents of 6,8-DibromoTHQ $\mathbf{2}$ and 6,8-diphenylquinoline $\mathbf{5}$ were investigated due to exhibition of their antiproliferative and apoptotic effects.

Keywords: Quinoline, tetrahydroquinoline, bromoquinoline, phenylquinoline, anticancer, cytotoxcity, apoptosis, Topoisomerase I ihhibitörü

\section{Giriş}

Kanser, insanlığın karşı karşıya kaldığı en önemli hastalıklardan birisi olup hala kesin bir tedavisi bulunamamıştır. Kanser tedavisi için milyarlarca dolar harcanarak yeni kanser ilaçları geliştirilmekte, fakat bunların bir kısmı ciddi yan etkileri ve dayanıklılık kazanılması nedeniyle kullanım dışı kalmaktadır. Bu nedenle, tedavi etme gücü yüksek ve yan etkisi düşük yeni ilaç bileşeni molekül sentezleme çalışmaları halen devam etmekte olup bilim insanlarının ilgi odağı haline gelmiştir.

Azot atomu ihtiva eden alkoloidler [1-3] doğal olarak biyolojik aktivite gösteren bileşiklerdir. Kinolin, kömür katranından ve Kınakına (Cinchona) ağacından elde edilen hetero halkalı önemli bir alkoloiddir. Tıp, eczacılık, biyoorganik, endüstri ve hatta sentetik organik kimya alanlarında geniş uygulama alanları bulunmaktadır. Kinolin ve yapılarında kinolin halkası bulunduran bileşikler antibakteriyel [4-5], antifungal [67], antitümor [8-9], HIV replikasyon inhibitörü [10] gibi geniş biyolojik aktivite göstermeleri sebebiyle heterosiklik bileşiklerin en önemli sınıflarından biridir ve tıpta tedavi etmek amaçlı ilaç olarak da kullanılmaktadır. Daha önceki yapılan çalışmalarda kinolin iskeletine sahip birçok molekülün anti kanser aktiviteleri rapor edilmiştir. Kinolin iskeletine sahip birçok ticari ilaç örneği bulunmaktadır (Şekil 1).<smiles>CCN(CC)CCCC(C)Nc1ccnc2cc(Cl)ccc12</smiles>

Chloroquine (Sitma ilaci)

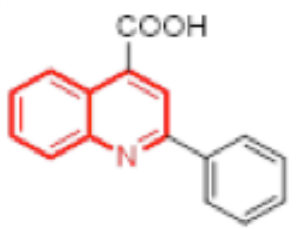

Atophan (Romatizma ilaci)<smiles>CC1CC1n1cc(C(=O)O)c(=O)c2cc(F)c(N3CCNCC3)cc21</smiles>

Ciproflaxicin (Antibiyotik)<smiles>COc1cc2nccc(Oc3ccc(NC(=O)NC4CC4)c(Cl)c3)c2cc1C(N)=O</smiles>

Lenvatinib (Antikanser ilaci)

Şekil 1. Ticari kinolin türevi ilaçlar 
Kinolin bileşiğinin analoglarından olan bromo kinolinler farmasötik kimya ve materyal endüstrisinde yeni sübstitüe kinolin türevlerinin sentezlenmesi amacıyla kimyacılar için çok önemli anahtar moleküllerdir $[8,11]$. Aromatik boronik asit ve bromo kinolin türevleri arasında gerçekleşen Suzuki çapraz kenetlenme reaksiyonları potansiyel biyo aktif yeni moleküllerin sentezi için önemli bir basamaktır [12]. Son yıllarda sitotoksik profillerini belirlemek amaçlı, palladyum katalizli çapraz kenetleme reaksiyonları ile 5,7-dibromokinolin molekülünden yola çıkılarak çok sayıda biyo aktif bileşik rapor edilmiştir [13]. Günümüzde kinolin iskeletine sahip farklı gruplarla sübstitüe bileşikler yaygın bir şekilde sentezlenmiştir ve çeşitli kanser hücrelerine karşı potansiyel anti kanser ajan oldukları rapor edilmiştir [8,14,15].

Önceki çalışmalarımızda 6,8-disübstitüe kinolinler için sentetik statejiler geliştirildi (Şema 1) [8,11]. Gurubumuz tarafından sentezlenen farklı sübstitüentlerle işlevsel hale getirilen kinolin türevlerinin antiproliferatif ve sitotoksik aktiviteleri gösterdiklerini ticari bir kanser ilacı olan 5-florourasil (5-FU) ile kıyaslanarak literatürde rapor edilmiştir [16-18].

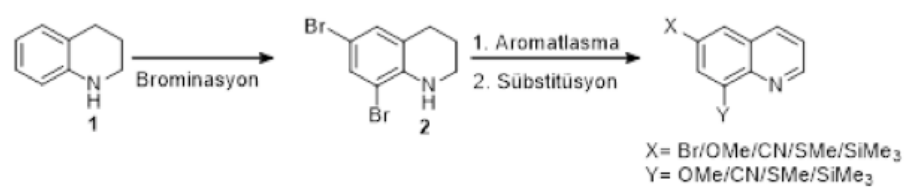

Şema 1. 6,8-disübstitüe kinolinler için sentetik stateji

$\mathrm{Bu}$ güncel çalışmamızda, kinolin çekirdeğinin C-6 ve C-8 konumlarında sübstitüe bir seri kinolin türevleri sentezlendi, kanser aktiviteleri incelendi ve sübstitüentlere bağlı olarak aktivitelerinin nasıl değiştiğine dair karşılaştırılma yapılmıştır. Bu amaçla, 6,8-disübstitüe kinolin türevlerinin HeLa, HT29 ve C6 kanser hücre hatlarına karşı antiproliferatif etkilerini karşılaştırmalı olarak inceleyerek etki mekanizmalarını araştırmak için apoptosis, sitotoksisite ve antitopoisomeraz özellikleri çalışılmıştır.

\section{Gereç ve Yöntemler}

\section{6,8-Disübstitüe Kinolinlerin Eldesi}

Bütün reaktif ve çözücüler ticari olarak temin edildi. 6,8-Dibromo-1,2,3,4-tetrahidrokinolin (2), 6,8-dibromokinolin (3), 6,8-dimetoksikinolin (4) ve 6,8-disiyanokinolin (6) türevleri grubumuz tarafından literatürde rapor edilen yöntemlerle [8,19-20] sentezlendi ve yapıları IR, 'H NMR ve ${ }^{13} \mathrm{C}$ NMR spektrumları ile belirlenerek spektral veriler rapor edilen değerlerle teyit edilmiştir. 6,8-Difenilkinolin, 6,8-dibromokinolin'in $\mathrm{PhB}(\mathrm{OH})_{2}$ ile $\mathrm{Pd}\left(\mathrm{PPh}_{3}\right)_{4}$ ve $\mathrm{K}_{2} \mathrm{CO}_{3}$ çözeltisi eşliğinde argon atmosferinde 1,4-dioksan çözücüsünde kaynatılarak \%82 verimle sentezlendi. Bu molekülün yapısı IR, ${ }^{1} \mathrm{H}$ NMR ve ${ }^{13} \mathrm{C}$ NMR spektrumları ile aydınlatıldı. Spektral veriler sonuçlandırıldığımız Tübitak proje sonuç raporunda rapor edilmiştir [21].

\section{Hücre Hatları ve Hücre Kültürü}

Çalışmamızda C6, HT29 ve HeLa hücre hatları kullanılmıştır. C6 hücre hattı $\left(\right.$ ATCC $^{\circledR} \mathrm{CCL}^{107^{\mathrm{TM}}}$ ), Rattus norvegicus'un beyin dokusundan elde edilen, fibroblast morfolojisine sahip adherent özellik sergileyen glioma hücreleridir. HT29 hücre hattı (ATCC ${ }^{\circledR}$ HTB-38 $\left.{ }^{\mathrm{TM}}\right)$, insan kalın bağırsak dokusundan elde edilen ve epitel hücre morfolojisine sahip, adherent yapılı kolorektal adenokarsinoma hücreleridir. HeLa hücre hattı (ATCC ${ }^{\circledR} \mathrm{CCL} 2^{\mathrm{TM}}$ ) ise, morfolojik olarak epitel hücre yapısında, adherent özelliğe sahip insan serviks adenokarsinoma hücreleridir. Söz konusu hücre hatları ATCC'den temin edilmiş, hücre kültürü ile çoğaltılmış ve sıvı nitrojen içerisinde $\left(-196^{\circ} \mathrm{C}\right)$ muhafaza edilmiştir.

Hücre kültüründe amaç, hücrelerin in vitro şartlar altında yaşayıp çoğalmalarını sağlamaktır. Kullanılan hücre hatlarına uygun olarak seçilen ve hücrelerin proliferasyonları için gerekli tüm öğeleri barındıran besiyeri, hücrelerin yaşam ortamını oluşturmaktadır. Besiyeri olarak; \%5 FBS, \%2 penisilin-streptomisin ve $0.22 \mathrm{NaHCO}_{3}$ içeren DMEM (Dulbecco's Modified Eagles Medium, High Glucose (4.5 g/L) kullanılmıştır. T75 hücre kültür flasklarındaki besiyeri içerisine alınan hücreler $37^{\circ} \mathrm{C}$ 'de, $\% 5 \mathrm{CO}_{2}$ içeren ortamda, ortalama 60-72 saat inkübe edilerek büyümeleri sağlanmıştır. Bulunduğu kültür flaskında \%80 büyüme kaydeden hücreler (konfluent) deney için hazır hale gelmiştir.

\section{BrdU Hücre Proliferasyonu ELISA}

Hücre proliferasyonunun belirlenmesi amacıyla kolorimetrik Hücre Proliferasyon ELISA (Enzyme Linked Immunosorbent Assay) yöntemi kullanılmıştır. BrdU Cell Proliferation ELISA (BCPE), kiti firmanın (Roche) prosedürüne göre kullanılmıştır. BCPE kiti içeriği BrdU labeling reagent, FixDenat, Anti-BrdUPOD, Antibody Dilution Solution, Washing Buffer PBS ve Substrate Solution olmak üzere altı solüsyondan meydana gelmektedir. 96 kuyucuklu plate kullanılarak, her kuyuda 0.1 $\mathrm{mL}$ besiyeri içerisinde $3 \times 10^{3}$ hücre olacak şekilde pipetlenen hücreler 24 saat süreyle inkübasyona bırakıldı. 1:100 oranında BrdU:DMEM eklenerek hazırlanan BrdU labeling reagent, $20 \mu \mathrm{L} /$ kuyu şeklinde pipetlenerek $37^{\circ} \mathrm{C}$ 'de, \%95 nem ve \%5 
$\mathrm{CO}_{2}$ içeren kültür ortamında 4 saat inkübe edildi. İnkübasyon sonrasında kuyu içerikleri aspire edilerek $100 \mu \mathrm{L} /$ kuyu olacak şekilde FixDenat solüsyonu eklenedi 45 dakika oda Isısında bekletildi. Ardından aspire edilen kuyular üzerine $50 \mu \mathrm{L} /$ kuyu olacak şekilde Anti-BrdU-POD ilave edilerek oda Isısında 2 saat bırakıldı. Daha sonra plate içeriği aspire edildi ve 1:10 oranında washing buffer: $\mathrm{ddH}_{2} \mathrm{O}$ şeklinde hazırlanan yıkama solüsyonuyla $200 \mu \mathrm{L} /$ kuyu olacak şekilde 3 kez yıkama yapıldı. Bu işlemin devamında kullanıma hazır olan substrat solüsyonundan her bir kuyuya $50 \mu \mathrm{L}$ eklenerek 45 dakika süreyle oda ısısında bekletildi. Süre sonunda reaksiyonu sonlandırmak için $1 \mathrm{M} \mathrm{H}_{2} \mathrm{SO}_{4}$ 'den $25 \mu \mathrm{L}$ /kuyu ilave edilerek 450$650 \mathrm{~nm}$ dalga boyunda spektrofotometrik ELISA mikroplate okuyucu ile absorbans değerleri kaydedildi. Testler üç tekrarlı olarak gerçekleştirilmiştir. \% inhibisyon değeri aşağıdaki formüle göre hesaplandı.

\% İnhibisyon $=[100 \times$ (Hücre Kontrol - Deney $)] /($ Hücre Kontrol $)$

\% Kontrol Hücre Büyüme = (OD örnek - OD 0.gün) / (OD negatif kontrol - OD 0.gün)

\% Büyüme İnhibisyonu = 100 - \% Kontrol Hücre Büyüme

\section{LDH Sitotoksisite Testi}

Hücre sitotoksisitesi plazma membran hasarıyla yakından ilişkili olup farklı yöntemlerle tespit edilebilmektedir. Bunlardan birisi membran hasarlı hücrelerden salınan sitoplazmik Laktat dehidrogenaz (LDH) enziminin aktivitesinin ölçümüne dayanır. LDH, tüm hücrelerde bulunan stabil sitoplazmik bir enzim olup plazma membranında bir zarar meydana geldiğinde hızlıca hücre kültür süpernatantına karışır. Böylece uygulanan test maddesinin, sitotoksik olup olmadığı LDH varlığı veya LDH enzim aktivitesi miktarı belirlenerek tespit edilir. LDH sitotoksisite testi, LDH sitotoksisite kiti (Roche) ve üreticinin prosedürüne göre gerçekleştirilmiştir. LDH sitotoksisite testi için, test edilecek madde miktarına bağlı olmakla birlikte 96 kuyucuklu plate kullanıldı ve $100 \mu$ L'de 5000 hücre/kuyu olacak şekilde triplike olarak ekim yapıldı. Test maddeleri IC konsantrasyonlarında kuyulara eklendikten sonra total hacim DMEM ile total hacim $200 \mu L^{\prime} y e$ tamamlandı. Background kontrolde hücre olmayıp yalnızca $200 \mu \mathrm{L}$ DMEM bulunurken, düşük kontrolde $100 \mu \mathrm{L}$ hücre ve $100 \mu \mathrm{L}$ DMEM, yüksek kontrolde ise $100 \mu \mathrm{L}$ hücre ve $100 \mu \mathrm{L} \% 2^{\prime}$ lik TritonX-100 bulunur ve plate 24 saat süreyle $37^{\circ} \mathrm{C}^{\prime}$ de, $\% 95$ nem ve $\% 5 \mathrm{CO}_{2}$ içeren kültür ortamında inkübe edildi. Süre sonunda her bir kuyudan $100 \mu \mathrm{L}$ süpernatant alınarak, aynı şekilde etiketlenmiş yeni plate kuyucuğuna eklendi. Yaklaşık 100 test için, 11.25 mL Dye içerisine $250 \mu \mathrm{L}$ katalist ilave edilerek reaksiyon karışımı hazırlandı ve tek kullanımlık olarak hazırlanan bu reaksiyon karışımı $100 \mu \mathrm{L} /$ kuyu olacak şekilde eklendi. 20 dakika oda ısısında ve karanlıkta inkübe edildi. $492-630 \mathrm{~nm}$ dalga boyunda absorbans değerleri kaydedildi. \% Sitotoksisiteyi hesaplamak için triplike kuyuların ortalama absorbansları alınarak her birinden background kontrolün ortalama absorbans değeri çıkarıldı (A). Elde edilen sonuçlar üzerinden aşağıdaki formül kullanılarak \% sitotoksisite hesaplandı.

\% Sitotoksisite $=[(\mathrm{A}-$ Düşük Kontrol) $/($ Yüksek Kontrol Düşük Kontrol)] x 100

\section{DNA Bantlaşma Testi}

Antiproliferatif özellik gösteren 6,8-disübstitüe kinolin analoglarının apoptotik özelliklerini değerlendirmek için Gong ve ark. (1994)'nın izlediği DNA bantlaşma yöntemi takip edilmiştir [22]. $75 \mathrm{~cm}^{2}$ 'lik hücre kültür flaskında büyüyen hücreler, $6 \mathrm{~mL}$ içerisinde 750000 hücre olacak şekilde 25 cm2'lik küçük kültür flasklarına ekilerek 24 saat süreyle hücre kültür ortamında inkübe edildi. Süre sonunda $I C_{50}$ değeri üzerinden test maddeleri ilave edilerek 24 saat süreyle tekrar inkübasyona bırakıldı. İnkübasyon sonrası flask içeriğindeki adherent hücreler, kazıyıcı yardımıyla kaldırılarıldı ve 15 mL'lik bir falkona alınarak 6000 rpm'de 5 dk santrifüj edildi. Dipte oluşan pellete zarar vermeden süpernatatant aspire edildi. Pellet üzerine 200 mL DPBS ilave edilerek, hücrelerin dağılması sağlandı. Ardından üzerlerine $5 \mathrm{~mL} \% 70$ 'lik etil alkol ilave edilerek 48 saat boyunca $-20^{\circ} \mathrm{C}$ 'de muhafaza edildi. Süre sonunda santrifüj edilerek, alkol ortamdan çekildi. Dipte kalan az miktarda alkolün de uçması ve hücrelerin tamamen kuruyabilmesi için $37^{\circ} \mathrm{C}$ 'de, ısıtıcılı bir karıştırıcıda yaklaşık 2 saat bırakıldı. Hücre pelletinin tamamen kuruduğuna emin olduğumuzda, hazırladığımız fosfat-sitrat tamponundan $50 \mu \mathrm{L}$ ilave ederek, hücre pelletinin çözülmesi sağlanır ve ardından 30 dakika daha $37^{\circ} C^{\prime}$ 'de inkübe edildi. Ardından hücreler santrifüj edildi ve düşük molekül ağırlıklı DNA'nın bulunduğu süpernatant kısımdan $40 \mu \mathrm{L}$ alınarak bir eppendorf tüpüne aktarıldı. Üzerine $5 \mu \mathrm{L}$ RNaz A ve $5 \mu \mathrm{L}$ Tween20 ilavesiyle 37 'C'de $30 \mathrm{dk}$ inkübasyona bırakıldı. Son olarak üzerine $5 \mu \mathrm{L}$ proteinaz Kilave edilerek $37^{\circ} \mathrm{C}$ 'de 30 dakika inkübe edildi. Işlem sonunda örneklerin üzerine $5 \mu \mathrm{L}$ loading dye eklenerek \% 2'lik agaroz jelde yürütüldü. Elektroforez işlemi tamamlandığında jel görüntüleme sistemi kullanılarak DNA'da merdiven gibi bantlaşma varlığı tespit edildi. 


\section{DNA Topoizomeraz I inhibisyon Testi}

Antiproliferatif özelliğe sahip olduğu saptanan kinolin türevi bileşiklerin, topoizomeraz I inhibisyon aktiviteleri, topoizomeraz I inhibisyon kiti (TopoGEN) kullanılarak belirlenmiştir. Topoizomeraz I enzim inhibisyon testi için kit prosedürü izlenmiştir. Test edilecek her bir madde için, kit içeriğinde yer alan 10xTGS Buffer'dan $2 \mu \mathrm{L}$, super sarımlı DNA (pHOT1 DNA)'dan $1 \mu \mathrm{L}$, topoizomeraz I'den $1 \mu \mathrm{L}$ bir PCR tüpünün içine alındı ve üzeri $\mathrm{ddH}_{2} \mathrm{O}$ ile $20 \mu \mathrm{L}^{\prime}$ ye tamamlandı. 37 'C'de yaklaşık 30 dakika inkübe edildi. İnkübasyon sonrasında her bir PCR tüpü içerisine $5 \times$ Stop Solüsyonundan $4 \mu \mathrm{L}$ eklendi ve EtBr'süz \%1'lik agaroz jel elektroforezde 2 saat yürütüldü.

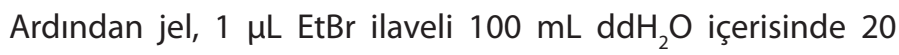
dakika boyamaya bırakıldı ve jel, $100 \mathrm{~mL}$ dd $_{2} \mathrm{O}$ içerisinde 15 dakika bekletilerek fotoğraflandı.

\section{İstatistiksel Analiz ve IC $_{50}$ değerlerinin hesaplanması}

Çalışmamızda her bir test, kuyular triplike olacak şekilde farklı zamanlarda üç kez tekrarlanarak $(3 \times 3)$ yapılmıştır. Elde edilen absorbans değerlerinden \% sitotoksisite ve \% inhibisyon oranları ve SEM ve \pm SD değerleri Microsoft Excel programıla hesaplanmıştır. Elde edilen \% sitotoksisite ve \% inhibisyon sonuçları varyans analizi SPSS (Statistic Program for Social and Science) programı yardımıyla, one-way ANOVA testi kullanılarak yapılmıştır. ANOVA testi doğruluk değeri $p<0.05$ olarak kabul edilmiştir. Test edilen kinolin bileşiklerinin $\mathrm{IC}_{50}$ konsantrasyonları, BCPE test sonuçları üzerinden XLfit5 (IDBS, USA) programı yardımıyla ve \%95 güven aralığında hesaplanmıştır.

\section{Bulgular}

\section{Kimya}

Ucuz bir ticari materyal olan 1,2,3,4-tetrahidrokinolinden (THQ, 1) başlayarak literatürde rapor edilen prosedüre uygun olarak 6,8-dibromokinolin (3) bileşiği iki adımda hazırlanmıştır (Şema 2) [20]. THQ'in 1, moleküler bromla muamelesi sonucunda yüksek bir verimde (\%92) 6,8-dibromo-1,2,3,4tetrahidrokinolin (6,8-diBrTHQ, 2) molekülü sentezlendi. $\mathrm{Bu}$ bileşik (2) DDQ (Diklorodisiyanobenzokinon) ile aromatlaştırılarak, 6,8-disübstitüe kinolin bileşikleri için anahtar molekül olan 6,8-dibromokinolin (6,8-diBrQ, 3) \%90 verimle elde edildi (Şema 2).

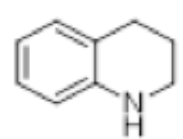
1
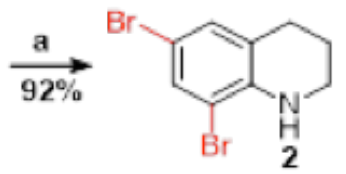
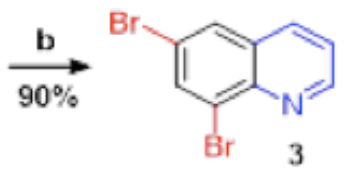

Şema 2. 6,8-Dibromo kinolinlerin 2 ve $\mathbf{3}$ sentezi. Reaktifler ve şartlar a) $\mathrm{Br}_{2}$ (2 eq), $\mathrm{CHCl}_{3^{\prime}} 2$ saat, $25^{\circ} \mathrm{C}$; b) DDQ (2 eq), benzen, $78^{\circ} \mathrm{C}, 3$ saat.
6,8-Dibromokinolin (3) molekülünün yapısındaki brom atomları sodyum metoksit ve bakır siyanür ile yer değiştirmesi sonucu iyi bir verimlerle 6,8-dimetoksikinolin (6,8-DiMeOQ, 3) ve 6,8-disiyanokinolin (6,8-DiCNQ, 6) analogları hazırlandı (Şema 3). Çalışma grubumuz tarafından 6,8-DiBrQ 3, C-6 ve C-8 konumlarında farklı sübstitüentlerle yer değiştirerek farklı hücre hatlarında antiproliferatif aktivitenin sübstitüente bağlı olarak değiştiği rapor edilmiştir [11]. Bu bileşiğin 3, C-6 ve C-8 konumlarında fenil aromatik halkası takılarak yeni kinolin türevinin hazırlanması hedeflendi. Yeni 6,8-difenilkinolin (6,8-diPhQ, 5), inert atmosfer altında ve katalitik miktarda $\mathrm{Pd}\left(\mathrm{PPh}_{3}\right)_{4} / \mathrm{K}_{2} \mathrm{CO}_{3}$ varlığında 6,8-dibromokinolin ve fenil boronik asit arasındaki Suzuki kenetlenme reaksiyonu ile iyi bir verimle hazırlandı (Şema 3).

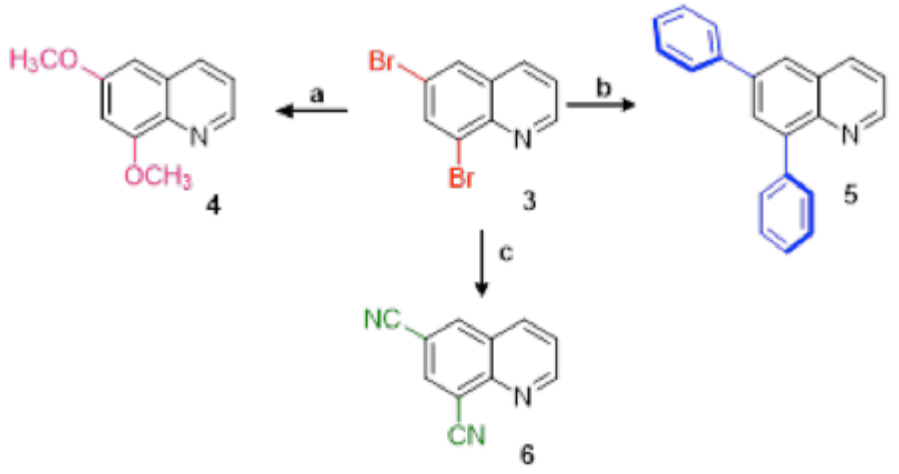

Şema 3. 6,8-Disübstitüe kinolinlerin 4 ve 5 sentezi. Reaktifler ve şartlar a) NaOMe, DMF, Cul, $150^{\circ} \mathrm{C}, 4$ saat; b) $\mathrm{PhB}(\mathrm{OH})_{2}$ (2 eq), 1,4-dioksan, $\mathrm{Pd}\left(\mathrm{PPh}_{3}\right)_{4^{\prime}} \mathrm{K}_{2} \mathrm{CO}_{3^{\prime}} 85^{\circ} \mathrm{C}, 5$ saat; $\left.\mathrm{C}\right) \mathrm{CuCN}(4 \mathrm{eq}), \mathrm{DMF}, 150^{\circ} \mathrm{C}, 6$ saat.

\section{Antiproliferatif aktivite çalışmaları}

Bu çalışmada, 2, 3, 4, 5 ve $\mathbf{6}$ nolu bileşiklerin HeLa, HT29 ve C6 kanser hücre hatlarına karşı 5, 10, 20, 30, 40, 50, 60 ve 75 g/ $\mathrm{mL}$ konsantrasyonlarında antiproliferatif aktiviteleri belirlendi. Kontrol bileşiği olarak ticari bir kanser ilacı olan 5-florourasil (5-FU) kullanılmış ve 6,8-disübstitüe kinolin analoglarının antiproliferatif aktiviteleri bu bileşikle karşılaştırılmıştır. Tüm hücre hatlarına karşı antiproliferatif aktivitesi en yüksek 6,8-diBrTHQ 2 bileşiği olarak belirlenmiştir. 6,8-diBrTHQ 2 ve 6,8-diPhQ 5, $40 \mu \mathrm{g} / \mathrm{mL}$ ve daha yüksek konsantrasyonlarda 5-FU'ya nazaran HeLa hücre hatlarının proliferasyonunu önemli derecede inhibe etmiştir ( $p<0.05$ ). HT29 hücre hatlarına karşı 2, 3 ve 4'ün yüksek inhibisyonlarına karşın 6,8-DiPhQ 5 ise 5-FU ile yakın bir inhibisyon gösterdiği belirlenmiştir. Bileşik 5, başlangıç bileşiği olan 6,8-diBrQ (3) ve kontrol bileşiği (5-FU) ile karşılaştırıldığında C6 hücre hattında daha yüksek inhibisyon gösterirken, tetrahidrokinolin (1) 
molekülünden sentezlenen ilk türev olan 6,8-DiBrTHQ 2, 30 $\mu \mathrm{g} / \mathrm{mL}$ ve daha yüksek konsantrasyonlarda önemli derecede inhibe ettiği $(p<0.05)$ Şekil 2'de görülmektedir. Tablo 1'de verilen $\mathrm{IC}_{50}$ değerlerinden görüleceği üzere test edilen kanser

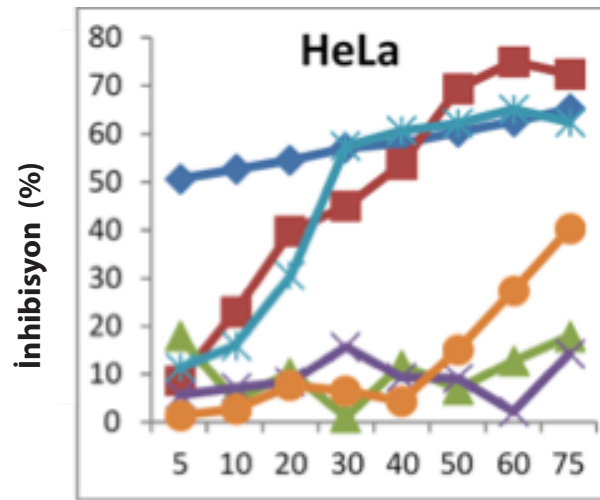

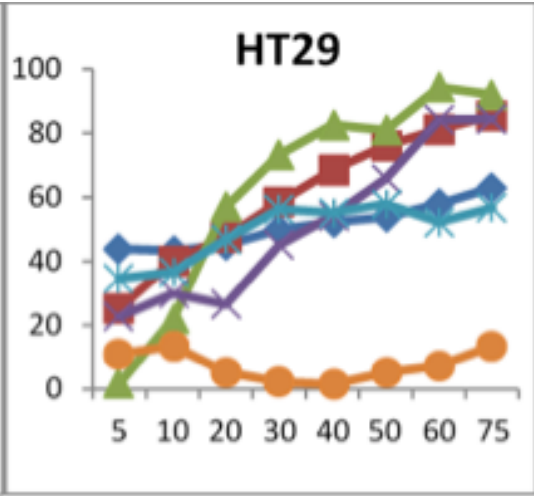

Konsantrasyon (ug/mL) hücre hatları üzerinde en iyi inhibisyon yüzdesi 6,8-DiBrTHQ 2 ve 6,8-DiPhQ 5 bileşiklerine aittir. 6,8-DiCNQ 6 hiçbir hücre hattında aktivite göstermemiştir.

Şekil 2. Bileşik 2, 3, 4, 5 ve 6'nın HeLa, HT-29 ve C6 hücre hatlarına karşı antiproliferatif aktivite grafikleri. Hücre proliferasyonu BrdU hücre ELISA kiti kullanılarak hesaplanmıştır. Yüzde inhibisyon değerleri üç bağımsız deneyin triplike tekrarı ile belirlenmiştir $(p<0.05)$.

\begin{tabular}{|c|c|c|c|}
\hline \multirow{2}{*}{ Bileşikler } & \multicolumn{3}{|c|}{ Kanser Hücre Hatları } \\
\hline & $\mathrm{C6}$ & HeLa & HT29 \\
\hline 5-FU & 31.27 & 33.60 & 32.90 \\
\hline 2 & 26.11 & 22.70 & 21.30 \\
\hline 3 & - & - & 19.26 \\
\hline 4 & - & - & 31.19 \\
\hline 5 & 33.80 & 28.41 & 43.60 \\
\hline
\end{tabular}

\section{Sitotoksik aktivite çalışmaları}

Her bir bileşik için hesaplanan $\mathrm{IC}_{50}$ konsantrasyonlarında (Tablo 1) etkili oldukları kanser hücre hatlarına muamele edilerek in vitro sıvılarda Laktat dehidrojenaz enziminin yüzdesi hesaplanarak sitotoksisiteleri belirlenmiştir (Şekil 3). Bileşik 2'nin sitotoksisitesi \%10-\%34 $(p<0.05)$ aralığında olup test edilen hücre hatlarına karşı oldukça düşük değerde olduğu belirlenmiştir. Bu sonuçlar, 6,8-diBrTHQ (2) bileşiğinin bütün hücre hatlarındaki antiproliferatif etkisinin sitotoksik etki üzerinden değil farklı bir mekanizma üzerinden etkilediğini göstermektedir. Benzer şekilde 6,8-diBrQ 3 ve 6,8-diMeOQ 4 bileşiklerinin de etkili oldukları hücre hatlarında (C6 ve HT29) ortalama \%4-\%8 ( $p$ < 0.05) aralığında sitotoksisite göstermeleri bu bileşiklerin $\mathbf{3}$ ve $\mathbf{4}$ başka bir mekanizma ile etki ettiklerine delildir (Şekil 3). Fakat 6,8-diPhQ 5, HeLa hücre hattında \%1.5 ( $p<0.05)$ sitotoksisite gösterirken, C6 ve HT29 hücre hatlarında (sırayla \%48 ve \%82) ( $p<0.05$ ) yüksek sitotoksisite göstermiştir. Bu veriler, 6,8-diPhQ'in 5 özellikle HT29 hücre hattına karşı antiproliferatif etkisinin sitotoksik etki ile yaptığını ifade edebiliriz.

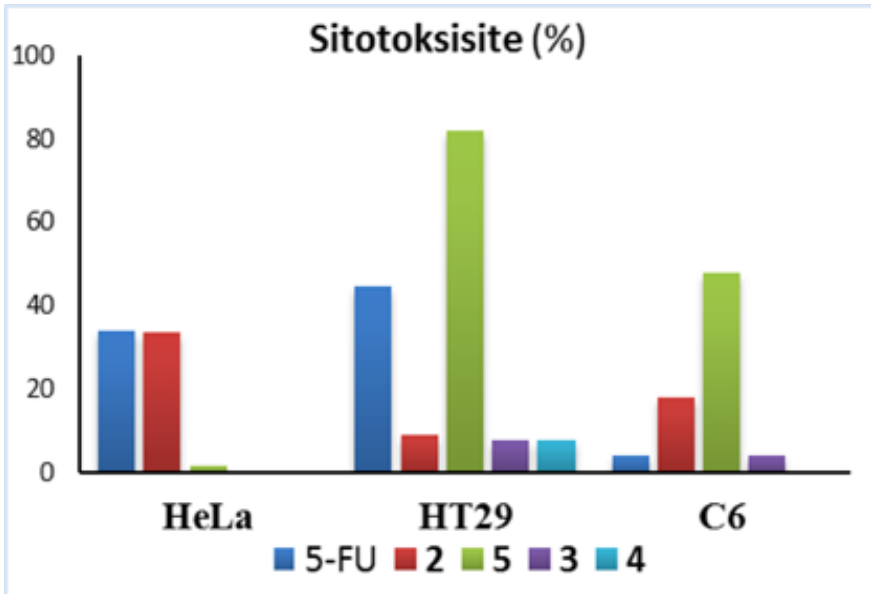

Şekil 3. Bileşik 2, 3, 4 ve $\mathbf{5}^{\prime}$ in HeLa, HT29 ve C6 hücre hatlarında sitotoksik aktivite grafikleri. Logaritmik çoğalan hücreler 2, 3, 4 ve $5^{\prime}$ in $\mathrm{IC}_{50}$ konsantrasyonlarında inkübe edildi ve Lactate dehydrogenase (LDH) sitotoksisite kiti kullanılarak bileşiklerin sitotoksisiteleri belirlendi. Yüzde sitotoksisite değerleri üç bağımsız deneyin üç kez tekrarı ile belirlenmiştir $(p<0.05)$.

\section{DNA bantlaşma deneyi ile bileşiklerin Apoptotik potansiyellerinin belirlenmesi}

Bileşikler antiproliferatif etkisinin olduğu hücre hatlarında apoptototik etkileri DNA bantlaşma deneyi ile belirlenmiştir. Elektroforofez jel görüntülerinde sadece 6,8-dibromo1,2,3,4-tetrahidrokinolin (2) molekülü C6 hücrelerinin DNA fragmentasyonuna sebep olduğunu göstermektedir. Bu sonuç, 6,8-diBrTHQ'nin 2 C6 hücre hattında apoptozisin uyarılmasıyla antiproliferatif aktivite gösterdiğine işaret etmektedir. Diğer bileşiklerin ise farklı mekanizma ile etki ettiklerini ifade edebiliriz. 


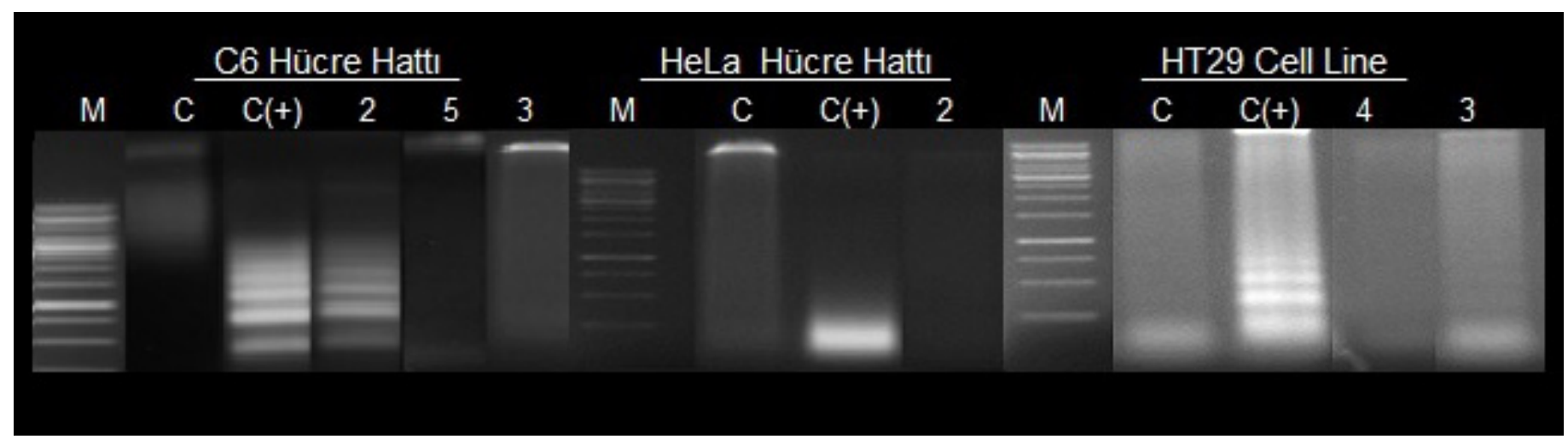

Şekil 4. Bileşik 2, 3, 4 ve 5'in HeLa, HT29 ve C6 hücre hatlarında DNA bantlaşma deneyi (Apoptoz). Test edilen Hücrelerin DNA'sı izole edilerek 1.5\% jel'de elektroforez edilmiştir. Veriler üç farklı deneyin üç kez tekrarı ile elde edilmiştir. (M; 1 kb Markır; Control, madde muamele edilmemiş hücre DNA'sl; (+) C, Camptothesin.

\section{Bileşiklerin Topoizomeraz I Enzimi Üzerine Etkisinin İncelenmesi}

DNA topoizomeraz I, DNA'nın topolojik halinin kontrol etmede önemli rol oynayan nükleer bir enzimdir. Bu enzim, DNA reeplikasyonu ve tamiri gibi hücre için hayati önem taşıyan fonsiyonlar için engelleri ortadan kaldırarak bu faaliyetleri kolaylaştırır. Kanser hücrelerinin replikasyonunu durdurmak kanser hücrelerinin kontrol altına almak için önemli bir adımdır. Test edilen 6,8-DiBrTHQ 2 ve 6,8-DiPhQ 5 bileşiklerinin Topo I enzimini yüksek oranda baskıladığı belirlenmiştir (Şekil 5). Bu bileşiklerin daha yüksek konsantrasyonlarda kullanıldığında enzim aktivitesinin tamamen bloke etmeleri beklenmektedir. Bakteri replikasyonu için zorunlu olan Topoizomeraz enzim aktivitesinin bu bileşiklerce baskılanması bu bileşiklerin muhtemelen yüksek anti bakteriyel aktiviteye sahip oldukları tahmin edilmektedir.

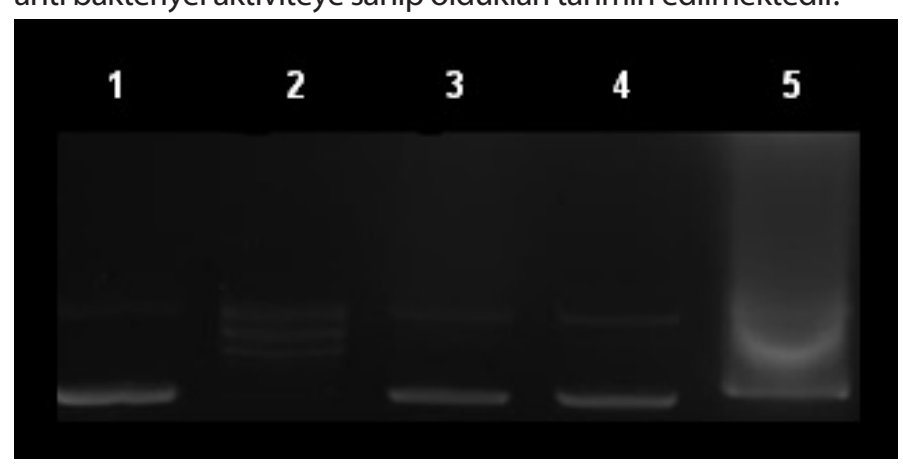

Şekil 5. 6,8-Disübstitüe kinolin türevlerinin Topoizomeraz I Enzim İnhibisyon Testi. 1: Relaks DNA (sarımları açılmış), 2: (-) Kontrol (Süper sarımlı DNA + Topo l) 3: (+) Kontrol (pHOT1 DNA + Camptothesin + Topo l), 4: Bileşik 2 + pHOT1 DNA + Topo I, 5: Bileşik 5 + pHOT1 DNA + Topo I.

\section{Tartışma}

6,8-Disübstitüe kinolin türevleri, C-6 ve C-8 pozisyonlarından bromlama, nükleofilik sübstitüsyon ve Suzuki çapraz kenetleme reaksiyonları ile sentezlendi. Yapı aktivite ilişkisi (SAR) temelinde, bu bileşikler HeLa, HT29 ve C6 hücre hatlarına karşı preklinik testler uygulandı. Konsantrasyona bağlı olarak 6,8-dibromoTHQ 2, 5-FU'ya kıyasla her üç hücre hattının proliferasyonun önemli derecede inhibe etmiştir (Şekil 2). Bu bileşiğin diğer analoglarının (3, 4 ve 5) antiproliferatif aktiviteleri değerlendirildiğinde, aromatik dibromür 3 ve disiyano 6, özellikle HeLa ve C6 hücre hatlarına karşı antiproliferatif doymuş dibromüre $\mathbf{2}$ nazaran önemli derecede azaldığı (Şekil 2) görülmüştür. 6,8-DiBrQ 3'den elde edilen 6,8-difenilkinolin (5) HeLa ve C6 hücrelerine karşı başlangıç maddesinin azalan antiproliferatif etkisini tekrar arttırmaktadır (Şekil 2). Benzer şekilde 6,8-DiBrQ 3'den elde edilen 6,8-dimetoksikinolin (4) ve 6,8-disiyanokinolin (6), diğer analoglara (2 ve 5) ve 5-FU nazaran HeLa ve C6 hücre hatlarında aktivite göstermemektedir. 6,8-DiMeOQ 4, HT29 hücre hatlarına karşı ise 5-FU'dan daha yüksek ve başlangıç maddesi (3) ile paralel bir aktivite göstermiştir ve $30 \mu \mathrm{g} / \mathrm{mL}$ üstündeki konsantrasyonlarda HT29 hücrelerinin proliferasyonunu inhibe etmiştir. Böylece 6,8-dimetoksikinolin (4) molekülünün hücre spesifik aktivite gösterdiği keşfedilmiştir.

LDH sitotoksik aktivite testlerinde, 6,8-difenilkinolin 5 HT29 hücrelerindeki sitotoksisitesi hariç, tüm bileşiklerin etkili oldukları hücre hatlarında sitotoksik aktiviteleri oldukça düşük seviyede olduğu görülmüştür (Şekil 3). Bu sonuç bileşik $\mathbf{5}^{\prime}$ in HT29 hücre hatlarındaki antiproliferatif aktivitesi sitotoksik etkisinin sebep olduğunu, diğer bileşikler (2-4) için ise farklı bir mekanizma ile etkilediğini söyleyebiliriz.

Bileşiklerin test edilen hücre hatlarındaki antiproliferatif ve sitotoksik etkilerini, C-6 ve C-8 konumlarına bağlı gruplar açısından değerlendirilmesini şu şekilde özetleyebiliriz: HT29 hücre hatlarına karşı kinolin halkasına $\mathrm{Br}$ ve OMe grupları takılı olduğunda önemli derecede inhibisyon gösterirken siyano ve fenil grupları, etkinin azalmasına sebep olmaktadır. Fakat, 6,8-diPhQ 5 5-FU'inkine yakın inhibisyon göstermektedir. Bu etkinin in vitro sıvılarda LDH seviyesini arttırdığından (Şekil 3) sitotoksik etki ile meydana gelmiş olabilir. HeLa ve C6 hücre hatlarında ise farklı bir sonuç ortaya çıkmıştır. 6,8-DibromoTHQ 2 her iki hücre hattında yüksek inhihisyon gösterirken bu bileşiğin aromatlaşması ve siyano $\boldsymbol{6}$ türevine dönüşmesi 
aktivitenin kaybolmasına sebep olmuştur. Aromatik dibromür'ün 3 brom atomları OMe ile yer değiştiğinde aktivite yükselmektedir. Ancak 6,8-DiBrQ 3 Suzuki kenetleme reaksiyonu ile $\mathrm{Ph}$ ile sübstitüe olduğunda HeLa ve C6 hücre hatlarında proliferasyonu inhibe etme özelliği kazanmıştır.

DNA bantlaşma deneyi ile 6,8-dibromoTHQ, 2 C6 hücre hattında DNA fregmatasyonuna sebep olurken HeLa hücre hattında bu etki görülmemektedir (Şekil 4). Bu sonuç, 2 nolu bileşiğin apoptosisi uyararak etki yaptığını göstermektedir. Topoizomeraz I enzimini inhibe eden $\mathbf{2}$ ve $\mathbf{5}$ DNA sarımının açılmasına engel olmaktadır (Şekil 5). Bu bileşiklerin (2 ve 5) Topo I enzimini baskılamasıyla DNA replikasyonuna engel olduğu ve kanser hücrelerinin proliferasyonunun inhibe ettikleri tahmin edilmektedir. Bu bileşiklerin yeni Topoisomeraz I inhibitörü ve antibakteriyel ajan adayı olduklarını ön görebiliriz.

Sonuç olarak, yaptığımız bu güncel çalışma 6,8-dibromoTHQ 2 ve 6,8-diPhQ 5 moleküllerinin antiproliferatif, sitotoksik ve apoptotik aktivite göstermeleri sebebiyle antikanser ilaç potansiyeline sahiptirler. Fakat, bu bileşiklerin antikanser ilaç olma potansiyelleri ve etki mekanizlarının daha iyi belilenmesi için ileri in vitro ve in vivo preklinik ve klinik çalışmalara ihtiyaç vardır.

\section{Maddi Destek ve Çıkar İlişkisi}

Çalışmayı maddi olarak destekleyen kişi/kuruluş yoktur ve yazarların çıkara dayalı bir ilişkisi yoktur.

\section{Maddi Destek ve Teşekkür}

Bu çalışma yürütülmesi için Türkiye Bilimsel ve Teknik Araştırma Kurumunun (TÜBITAK, Proje No: 112T394) maddi olarak desteklerinden dolayı teşekkür ederiz.

\section{Kaynaklar}

1. Manfred H. Alkaloids: Nature's Curse or Blessing? 1. Baskı. Weinheim, Wiley-VCH; 2002.

2. Poon CY, Chiu P, A synthesis of the tetracyclic carboskeleton of isaindigotidione. Tetrahedron Lett 2004; 45: 2985-8.

3. Jacquemond-Collet I, Benoit-Vical F, Valentin A, et al. Antiplasmodial and cytotoxic activity of galipinine and other tetrahydroquinolines from Galipea officinalis. Planta Med 2002; 68: 68-9.

4. Fang KC, Chen YL, Sheu J, et al. Synthesis, antibacterial, and cytotoxic evaluation of certain 7-substituted norfloxacin derivatives. J Med Chem 2000; 43: 3809-12.

5. Palit P, Paira P, Hazra A, et al. Phase transfer catalyzed synthesis of bisquinolines: Antileishmanial activity in experimental visceral leishmaniasis and in vitro antibacterial evaluation. Eur J Med Chem 2009; 44: 845-53.

6. Jampilek J, Dolezal M, Kunes J, et al. Investigating the antiproliferative activity of quinoline-5,8-diones and styrylquinolinecarboxylic acids on tumor cell lines. Med Chem 2005; 1: 591.
7. Musiol R, Jampilek J, Buchta V, et al. Antifungal properties of new series of quinoline derivatives. Bioorg Med Chem 2006; 14: 3592-8.

8. Ökten S, Çakmak O, Erenler R, et al. Simple and convenient preparation of novel 6,8-disubstituted quinoline derivatives and their promising anticancer activities. Turk J Chem 2013; 37: 896-908.

9. Ökten S, Şahin ÖY, Tekin Ş, et al. In vitro antiproliferative/ cytotoxic activity of novel quinoline compound SO-18 against various cancer cell lines. J Biotechn 2014; 185: S106.

10. Zouhiri F, Danet M, Benard C, et al. HIV-1 replication inhibitors of the styrylquinoline class: Introduction of an additional carboxyl group at the C-5 position of the quinoline. Tetrahedron Lett $2005 ; 46,2201-5$.

11. Şahin $A$, Çakmak $O$, Demirtaş 1 , et al. Efficent and selective synthesis of quinoline derivatives. Tetrahedron 2008; 64: 10068-74.

12. Broch S, Aboab B, Anizon F, et al. Synthesis and in vitro antiproliferative activities of quinoline derivatives. Eur J Med Chem 2010; 45: 1657-62.

13. Mphahlele MJ, Lesenyeho LG, Halogenated Quinolines as Substrates for the Palladium-Catalyzed Cross-Coupling Reactions to Afford Substituted Quinolines. J Heterocycl Chem 2013; 50: 1-16.

14. Solomon VR, Lee H. Chloroquine and its analogs: A new promise of an old drug for effective and safe cancer therapies. Eur J Pharmacol 2009; 625: 220-33.

15. Shi A, Nguyen TA, Battina SK, et al. Synthesis and anti-breast cancer activities of substituted quinolines. Bioorg Med Chem Lett 2008; 18: 3364-8.

16. Ökten S, Erenler R, Köprülü TK, et al. In vitro antiproliferative/ cytotoxic activity of 2,3'-biindole against various cancer cell lines. Turk J Biol 2015; 39: 15-22.

17. Şahin ÖY, Ökten S, Tekin Ş, et al. Determination of anticancer activities of some quinoline derivatives against $\mathrm{C} 6$ tumor cells. J Biotechn 2012; 161: S24.

18. Köprülü TK, Tekin Ş, Ökten S, et al. Detection of mechanism and anticancer activity of the new quinoline compounds MC20 and MC21. J Biotechn 2014; 185: S93.

19. Ökten S, Çakmak O. Synthesis of Novel Cyano Quinoline Derivatives. Tetrahedron Lett 2015; 56: 5337-40.

20. Ökten S, Eyigün D, Çakmak O. Synthesis of Brominated Quinolines. Sigma J Eng Nat Sci 2015; 33: 8-15.

21. Çakmak O, Ökten S, Tekin Ş. Bromlanmış Metoksi, Siyano ve Nitro/ amino Kinolin Türevlerinin Seçici-Etkin Sentezleri ve Biyolojik Aktivitelerinin İncelenmesi, 2014, 112 T394 no'lu Tübitak Projesi, Sonuç Raporu.

22. Gong J, Traganos F, Darzynkiewicz Z. A selective procedure for DNA extraction from apoptotic cells applicable for gel electrophoresis and flow cytometry. Anal Biochem 1994; 218: 314-9. 